\title{
BARRIER ISLAND RESTORATION FOR STORM DAMAGE REDUCTION: WILLAPA BAY, WASHINGTON, USA
}

\author{
David R. Michalsen ${ }^{1}$ Steven D. Babcock ${ }^{2}$ and Lihwa Lin $^{3}$
}

\begin{abstract}
The U.S. Army Corps of Engineers, Seattle District has completed a feasibility study and determined barrier island restoration to be the most appropriate long-term coastal flood and storm damage reduction measure for the Shoalwater Indian Reservation. Over the last century, Cape Shoalwater has receded more than 2.8 miles. By 1990, the Shoalwater Reservation's only remaining protection from storm wave attack was a series of barrier islands fronting Tokeland Peninsula. Extreme water levels coincident with strong winter storms have historically inundated this low lying topography and are responsible for the erosion and overwash of the protective barrier island known as Graveyard Spit. Here a simple risk assessment tool is presented for identifying flood risk to the Shoalwater Reservation infrastructure. Statistical analysis of extreme water levels and numerical modeling is utilized to determine the extent of inundation. From the analysis it was determined $54 \%$ of the inventoried infrastructure is at risk during a storm event equivalent to the observed event on March 3,1999. With the barrier island restoration it was found that this risk is reduced to $7 \%$.
\end{abstract}

Keywords: extreme water levels; barrier island restoration; flood risk; wave modeling;

\section{INTRODUCTION}

The Shoalwater Bay Indian Reservation is located on the northern shore of Willapa Bay, a large natural estuary located on the southwest coast of Washington State, USA. With a diurnal tidal prism of more than $2.5 \times 10^{10} \mathrm{ft}^{3}$ (Jarrett 1976), Willapa Bay is one of the largest inlets on the coast of the continental United States. The northern shoreline of Willapa Bay has changed substantially since the Shoalwater Reservation was established in 1866 (Terich and Levensellar 1986). Over the last century, portions of the Cape Shoalwater shoreline have receded more than 2.8 miles. By 1990 the Shoalwater Reservation only remaining protection from storm wave attack was a series of barrier islands fronting Tokeland Peninsula (see Figure 1). Tidal currents and storm waves have severely eroded the protective barrier islands known as Graveyard Spit. A series of breaches beginning in 1994 exposed the Reservation to increasing levels of flooding during extreme water levels. Erosion from storm overwash has filled North Cove with sand and significantly degraded and altered the habitat of the once protected embayment. The increased wave energy through North Cove has led to an increase in the severity and frequency of flooding and erosion of Reservation uplands during storm events. In 2000, the Assistant Secretary of the Army for Civil Works authorized the U.S. Army Corps of Engineers to construct and maintain a project at Federal expense. The feasibility of hard and soft engineering alternatives were evaluated by a multi agency technical team and the analysis determined barrier island dune restoration with periodic nourishment was the most appropriate long term solution to mitigate future erosion and flood damage risk (USACE 2009a).

\section{SITE CONDITIONS}

\section{Geology}

Graveyard Spit exists as a thin and fragmented landform that is anchored and aligned by consolidated and erosion-resistant Pleistocene substrate in the vicinity of the SR 105 emergency stabilization groin (Figure 1). Extending to the east of Graveyard Spit is a series of segmented sand islands. In contrast to historical conditions, this fragile line of barrier beaches no longer appears to receive sand supply from the eroding beach plain to the northwest. The lack of sand supply indicates that this landform will remain of low relief, compromising its historical function as a flood barrier for the Tokeland Peninsula.

Shoreline retreat along this northwest corner of North Cove has slowed substantially relative to historical rates of change, but the present condition and orientation of the spit suggest that it will continue to pivot towards the north-northeast from its hinge point at the base of the Pleistocene terrace.

\footnotetext{
${ }^{1}$ U.S. Army Corps of Engineers, Seattle District, P.O. Box 3755, Seattle, WA, 98124, USA.

David.r.michalsen@usace.army.mil

2 formerly of U.S. Army Corps of Engineers, Seattle District, P.O. Box 3755, Seattle, WA, 98124, USA

${ }^{3}$ US Army Engineer Research and Development Center, Coastal \& Hydraulics Laboratory, 3909 Halls Ferry Road, Vicksburg, MS. 39180, USA. Lihwa.lin@usace.army.mil
} 
Thus, the present condition of the spit is locally controlled by the geological framework of the region (USGS 2004)

\section{Tidal Currents, Water Levels, and Wave Climate}

Tidal currents are strong in the north entrance channel which is presently the main conveyance at the mouth. The primary entrance channel at the mouth has migrated from east-west to a northwest orientation since 1941 (Kraus 2000). Peak spring ebb currents through the north entrance channel are approximately 3.3 knots while peak flood currents are approximately 1.6 knots.

The mean tidal range at the entrance to Willapa Bay is $6.8 \mathrm{ft}$, and the peak spring tide elevation is approximately $11 \mathrm{ft}$ above mean lower low water (MLLW) as published by the National Ocean Service (NOS) of the National Oceanic and Atmospheric Administration (NOAA) at the Toke Point, Washington Station 9440910. In winter months spring tides are coincident with large storm events and are capable of producing water levels exceeding $5 \mathrm{ft}$ the predicted astronomical tide. Table 1 lists the maximum observed water levels at the Toke Point Station since 1973. Storm durations during such events range from 25 to 124 hours as shown in Figure 2.

Field measurements from a nearshore instrument deployed offshore of Graveyard Spit in December 2002 measured peak significant wave heights of approximately 3-4 feet during high tides (USACE 2009b). These field data confirmed wave energy is significantly dissipated by the offshore shoals at the entrance and the wave energy propagating over Graveyard Spit is tidally modulated.

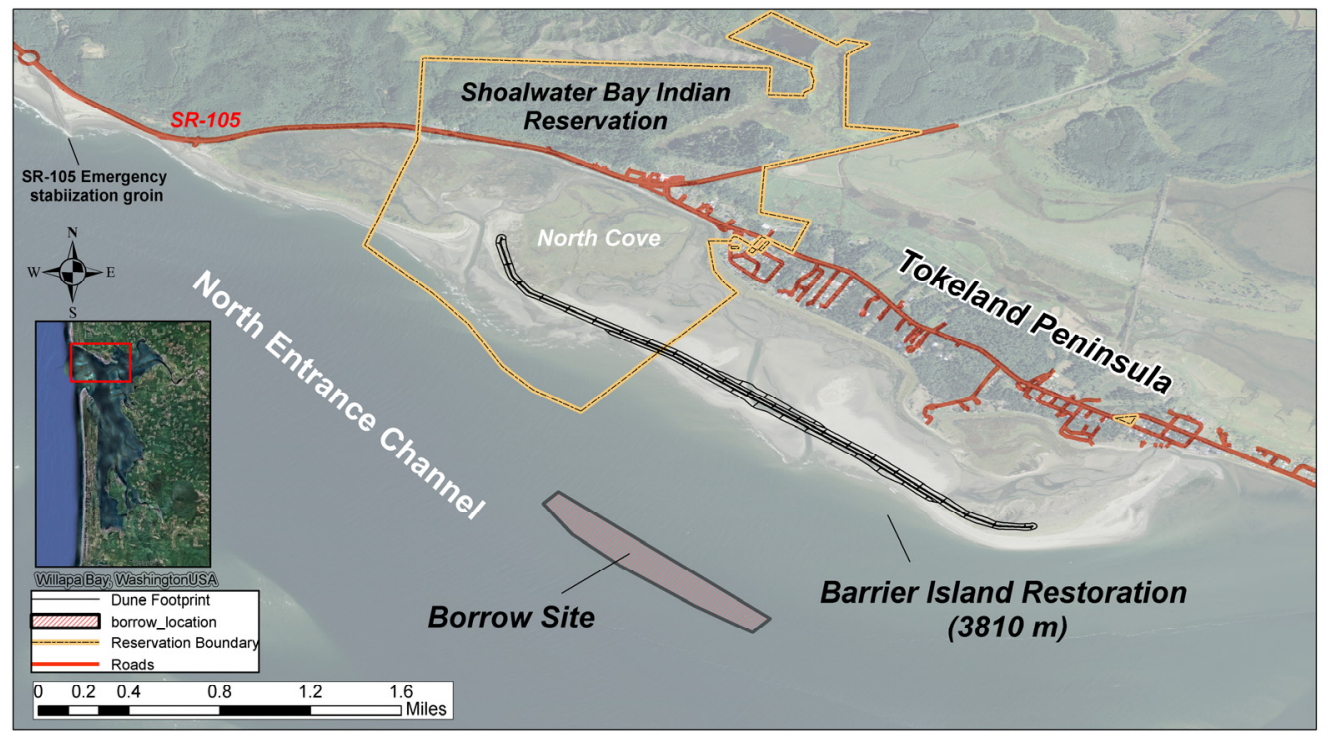

Figure 1. Shoalwater Bay - Barrier Island Restoration Project, Willapa Bay, Washington USA

\begin{tabular}{|c|c|c|c|}
\hline $\begin{array}{c}\text { TOTAL WATER } \\
\text { ELEVATION } \\
\text { (FEET, MLLW) }\end{array}$ & 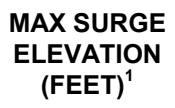 & $\begin{array}{l}\text { \% ANNUAL } \\
\text { OCCURRENCE } \\
\text { OF SURGE }\end{array}$ & DATE \\
\hline $\begin{array}{l}14.41 \\
14.07 \\
13.87 \\
13.61 \\
13.41 \\
13.36 \\
13.23 \\
13.21 \\
13.16 \\
13.09 \\
12.97 \\
12.95\end{array}$ & $\begin{array}{c}5.0 \\
4.4 \\
- \\
5.1 \\
5.3 \\
- \\
3.8 \\
3.3 \\
- \\
- \\
- \\
2.8\end{array}$ & $\begin{array}{c}5.6 \\
18.9 \\
- \\
4.5 \\
3.0 \\
- \\
54.3 \\
>100 \\
- \\
- \\
- \\
>100\end{array}$ & $\begin{array}{c}\text { November } 14,1981 \\
\text { February 4, } 2006 \\
\text { December } 11,1973 \\
\text { March 3, } 1999 \\
\text { December 3, } 2007 \\
\text { December 3, } 1982 \\
\text { December 1, } 2001 \\
\text { January 2, } 2003 \\
\text { January 27, } 1983 \\
\text { February 7, } 1978 \\
\text { January } 18,1973 \\
\text { January 29, } 1999\end{array}$ \\
\hline
\end{tabular}




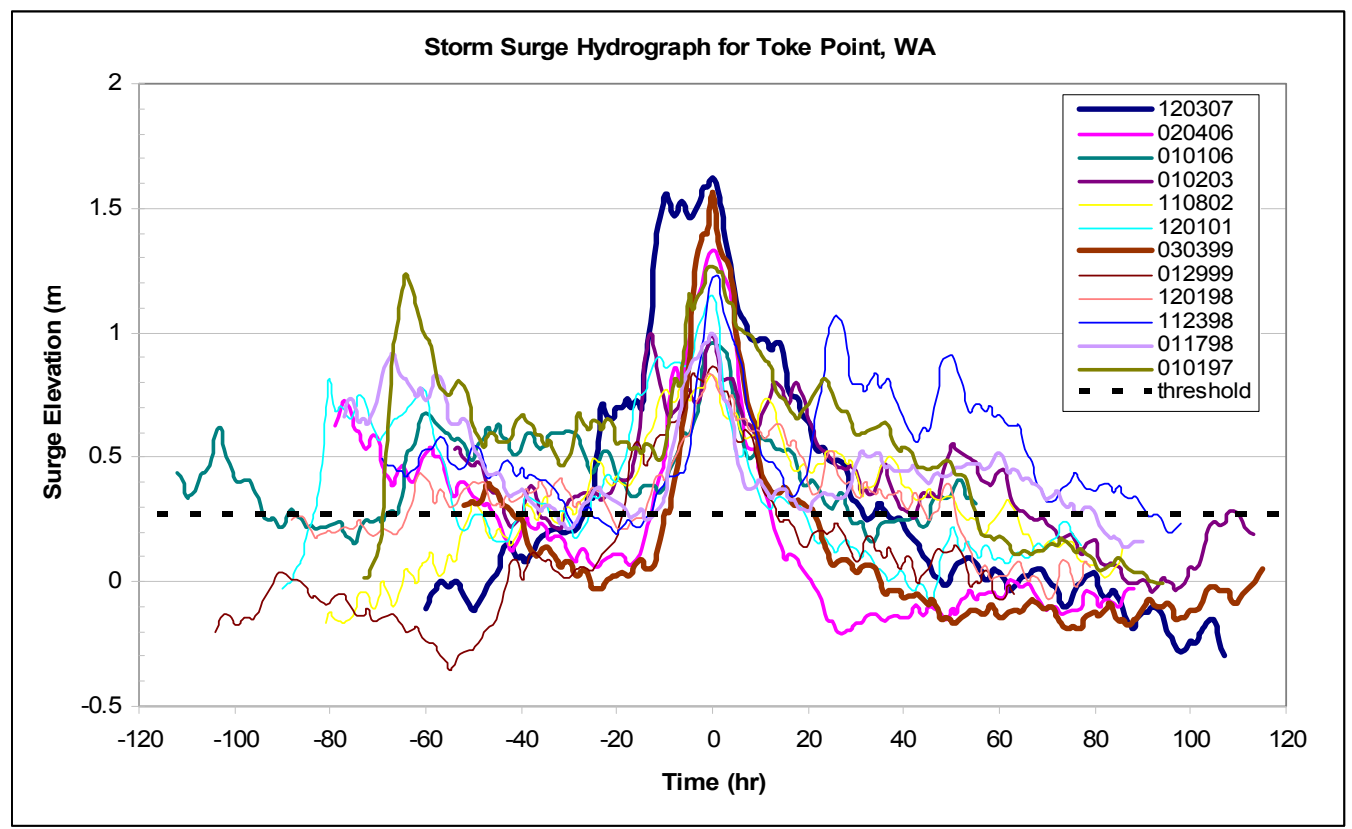

Figure 2. Peak storm surge hydrographs recorded at Toke Point Station 9440910.

\section{METHODOLOGY}

In order to determine flooding risk to the Shoalwater Indian Reservation infrastructure a statistical analysis was performed on the observed water levels and wave heights to generate the boundary conditions for the inundation model.

\section{Statistical analysis}

Extreme water levels are a combination of astronomical tide, storm surge, and wave setup. The tide component can be considered a deterministic event. Storm surge is a stochastic event and must be analyzed statistically using observed data to determine the frequency of occurrence of various surge elevations. In this analysis, storm surge is simply defined as the difference between the predicted astronomical tide and the observed tide. Figure 3 shows the joint distribution of tides and storm surge from 1980 to 2007. The coincidence of high tides and extreme storm surges is evident by data populated in the upper right corner of the figure. The frequency of high water levels can be computed from the joint distribution using the convolution method originally described by Pugh and Vassie (1978), assuming the surge and tides are statistically independent of one another. At Grayeyard spit it is well documented that surface gravity waves are tidally modulated suggesting storm surge is also dependent on tide and the convolution method may not be applicable. Instead, a simplified approach is utilized to develop the extreme water levels simulated in the inundation model. Representative tidal elevations of mean higher high water (MHHW) and maximum astronomical tide (MAT) are added to the storm surge extreme distribution to specify the initial water level conditions. The assumption is wave setup is minimal at the tide station. This is reasonable as the tide gage is located in the sheltered area on the bayside of Tokeland Peninsula. An extreme storm surge occurring at MHHW represents a likely occurrence while a peak storm surge coincident with MAT is less likely, but represents an upper limit to the extreme water levels in the area.

A peak over threshold analysis is performed to develop the storm surge extreme distribution. Storm surge elevations above a threshold of $3.3 \mathrm{ft}$ yielded $N_{T}=31$ events, or approximately one extreme event per year. The extreme distribution following a Fisher-Tippet type I (or Gumbel distribution) is fit to the data using the least squares method. The form of the cumulative distribution follows

$$
F(x)=\exp \left[-\exp \left(-\frac{x-B}{A}\right)\right] \quad:-\infty \leq x<\infty .
$$


where parameter $A$ governs the linear scale of $x$ and parameter $B$ fixes the location of the x-axis. The distribution is fit to the data using the unbiased plotting position formula outlined in (Goda 2000). Figure 4 shows the fitted distribution with the $90 \%$ confidence intervals. The storm surge return interval (in years) is calculated following the relation

$$
R=\frac{1}{\lambda\left[1-F\left(x_{u}\right)\right]},
$$

where $\lambda$ is the ratio of extreme samples to the number of years of data (e.g. $\left.\lambda=N_{T} / N\right)$, and $F\left(x_{u}\right)$ is the probability that the extreme variate $x$ does not exceed a given value $x_{u}$ in one year.

\section{Numerical wave modeling}

Three historical cases are modeled representing the three highest storm surge events on record since 1980. Additionally, six hypothetical storms are modeled. Table 2 lists the nine storm cases simulated. The hypothetical storms represent the 50,2, and $1 \%$ annual storm surge occurrence (i.e. the 2, 50, and 100 year return interval) occurring at MHHW and MAT. Extreme storm surge events are well correlated with wave height, period, and direction as these extreme events are almost always associated with south-southwesterly tracks. Extreme water levels combined with large offshore waves result in flooding to the Shoalwater Reservation shoreline. Documented damage to local infrastructure has typically been associated with dynamic flooding due to wave runup, overtopping, and overland wave propagation during these events.

CMS-Wave, is a two-dimensional (2D) spectral wave model formulated based on the wave action balance equation with energy dissipation and diffraction terms (Mase 2001; Mase et al. 2005). It simulates a steady-state spectral transformation of directional random waves co-existing with ambient currents in the coastal zone. The model operates on a coastal half-plane, implying waves can propagate only from the seaward boundary toward shore. It includes features such as wave generation, wave reflection, and bottom frictional dissipation. The model utilizes analytical relations to include wave setup, runup, and overtopping to compute inundation depths over low lying backshore regions (Lin et al. 2008).

\section{Data Sources}

The digital elevation model used to construct the numerical grid is generated from three sources. Topographic data from a photogrammetric survey in July 2008 are used to generate the Graveyard Spit condition and Tokeland Peninsula shoreline and backshore regions. Annual Corps hydrosurvey condition survey data from September 2008 of the north entrance channel and nearshore area are utilized for the surrounding bathymetry. Finally, the (Taylor et al. 2008) combined topography and bathymetry tsunami inundation digital elevation model is utilized for coverage outside these 2008 data. The model grid is constructed relative to the mean tide level (MTL) tidal datum.

The wave modeling is performed using a nested grid approach. A coarser regional scale grid with $200 \mathrm{ft}$ cell spacing is run to output wave information to "nesting cells" located at the offshore boundary of the higher resolution local scale grid. This $40 \mathrm{ft}$ cell spacing grid covers Tokeland Peninsula and the immediate offshore area. The two grids used in the simulations are shown in Figure 5.

Wave spectra for the cases listed in Table 2 are collected from the Grays Harbor Coastal Data Information Program (CDIP) 036 buoy located 13 miles northwest of the Entrance are utilized to specify the offshore wave boundary condition. For the case of the March 3, 1999 storm, there is a gap in the CDIP buoy data; therefore the spectra from the National Data Buoy Center (NDBC) buoy 46029 offshore the Mouth of the Columbia River located 43 miles southwest is utilized. In this case, the wave spectrum is transformed using the maximum entropy method to the $130 \mathrm{ft}$ depth, which corresponds to the water depth at the offshore boundary of the regional scale grid. Cells representing land are specified in the *.struct file to compute wave setup and runup.

\section{Model results and validation}

Model results indicate that the central breach through Graveyard Spit allows the most wave energy to enter North Cove. Alongshore wave height from Stations 1-22 are shown in Figure 5 for the March 3,1999 storm event. In the current condition, a maximum significant wave height of $\mathrm{H}_{\mathrm{s}}=2.8 \mathrm{ft}$, or $0.85 \mathrm{~m}$ is predicted at Station 18 . 


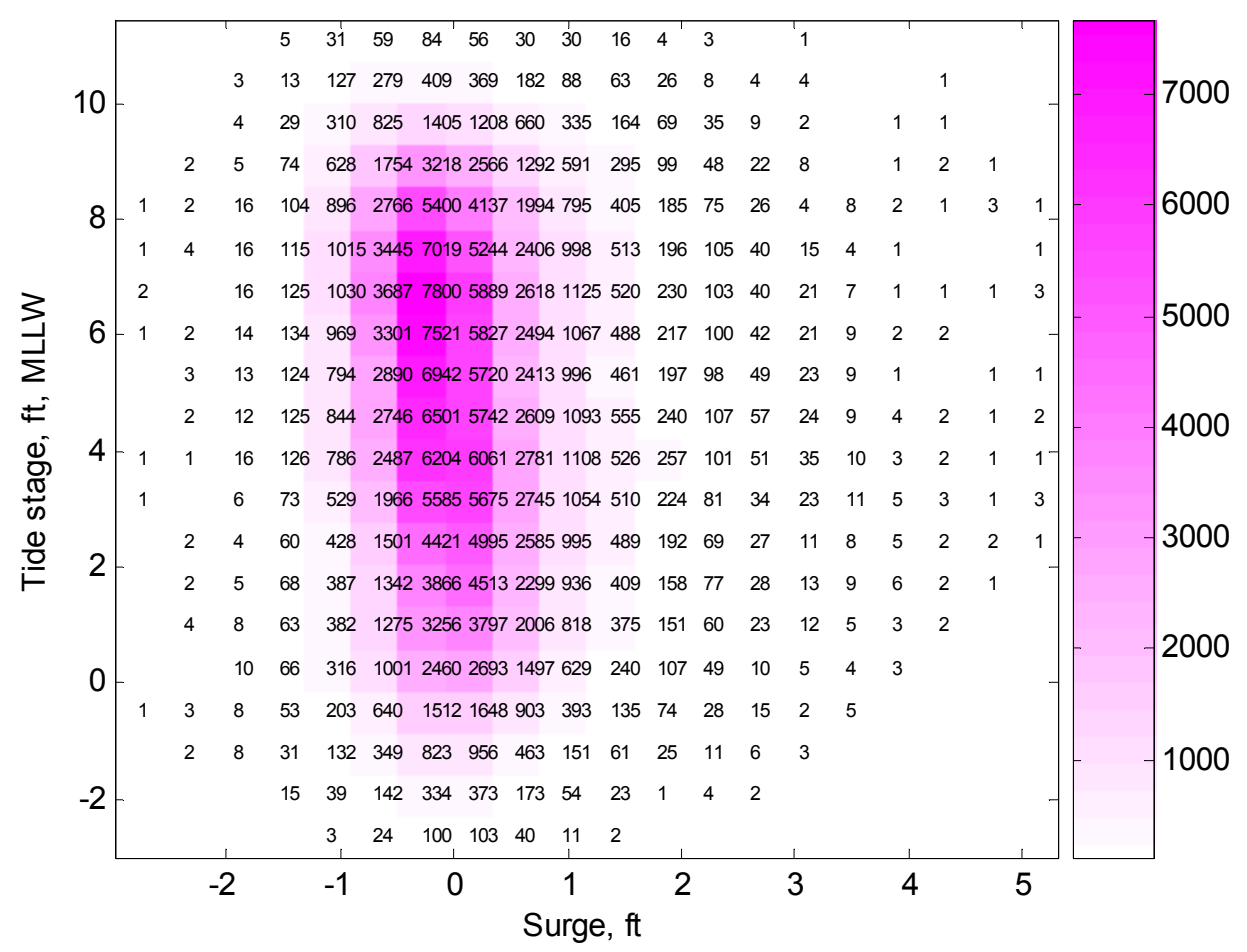

Figure 3. Toke Point Station 9440910 joint distribution of tide stage ( $\mathrm{ft}, \mathrm{MLLW}$ ) and storm surge (ft) from 1980-2007. Color scale represents number of events.

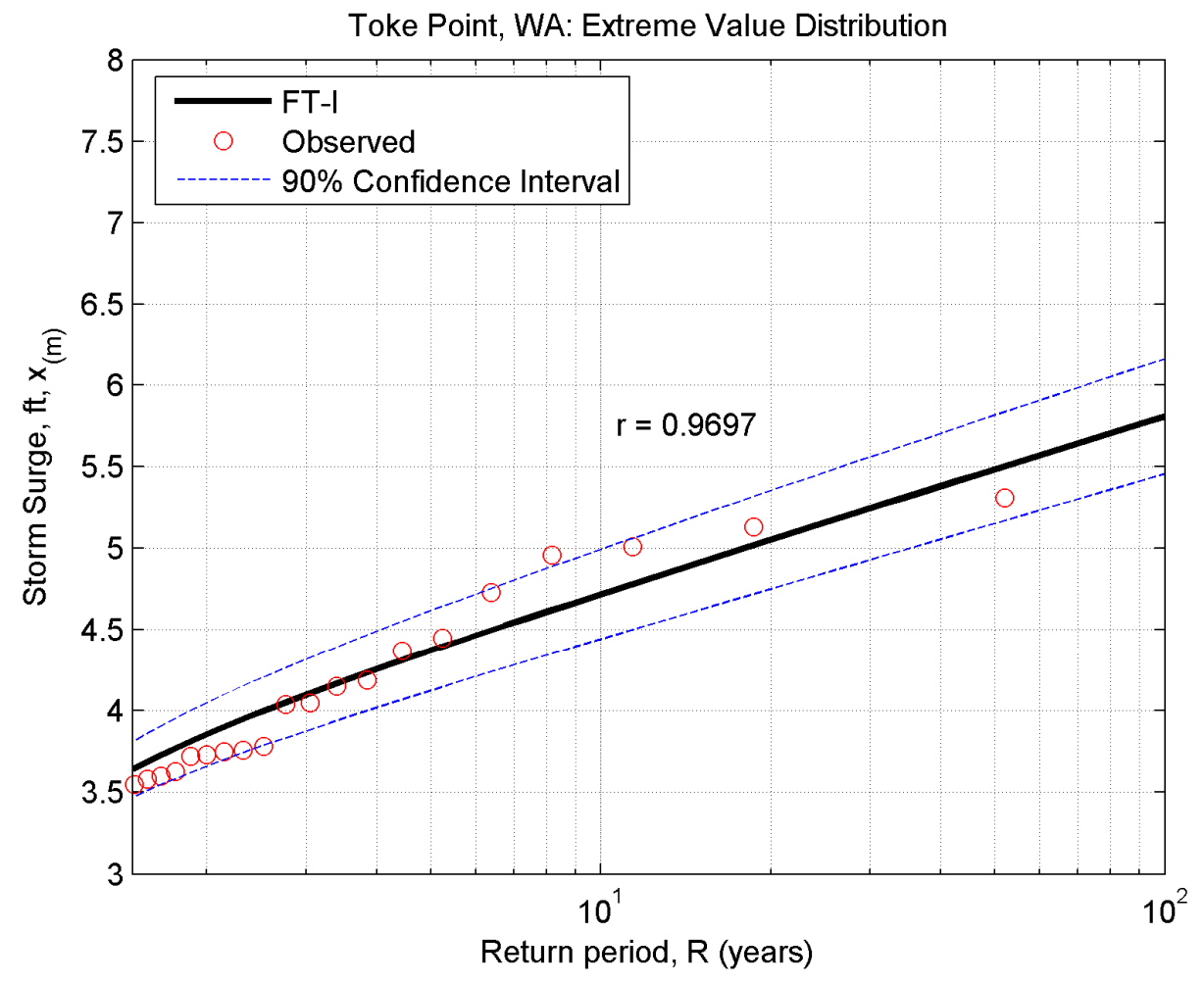

Figure 4. Storm surge elevation return interval in feet at Toke Point Station 9440910 


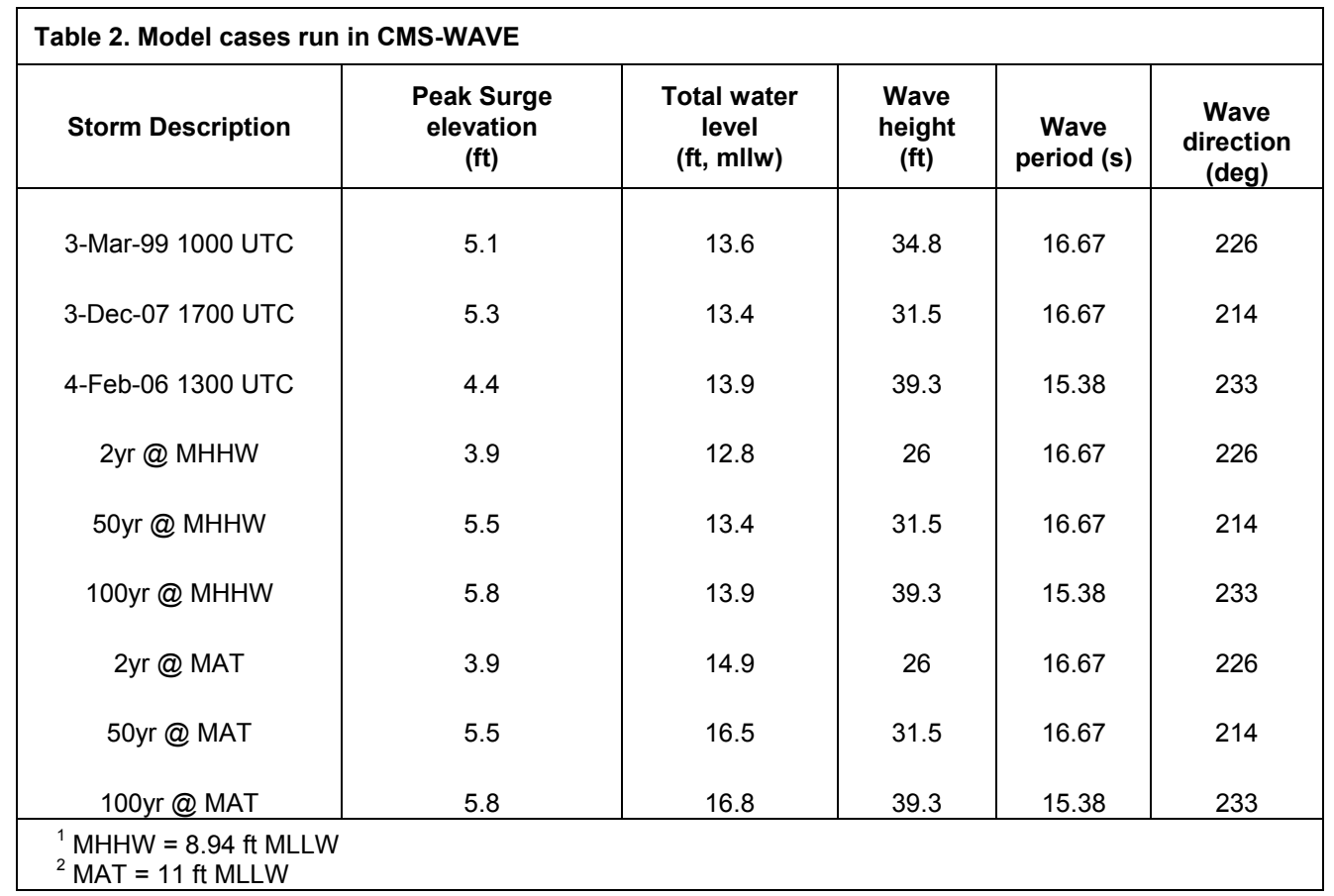

The increase in wave height through the breach brings potential adverse impacts such as larger wave runup on the shoreline and potential for greater storm related flooding. Figure 6 shows ground photos taken by members of the Shoalwater Reservation and demonstrates flood inundation and the consequences of overland wave propagation and debris damage associated with the March 3, 1999 and February 4, 2006 storms.

\section{Inundation Model}

Inundation depth is defined as the water depth associated with overland flooding. The maximum water depth can be a result of wave runup or inundation by rise in water levels due to tide and storm surge. The total wave runup consists of two components: (a) rise of the mean water level by wave breaking at the shore, known as the wave setup, and (b) swash of incident waves. Wave setup is computed as:

$$
\frac{\partial \eta}{\partial x}=-\frac{1}{\rho g h}\left(\frac{\partial S_{x x}}{\partial x}+\frac{\partial S_{x y}}{\partial y}\right) \quad, \quad \frac{\partial \eta}{\partial y}=-\frac{1}{\rho g h}\left(\frac{\partial S_{x y}}{\partial x}+\frac{\partial S_{y y}}{\partial y}\right)
$$

where $\rho$ is the water density and $S_{x x}, S_{x y}$, and $S_{y y}$ are radiation stress components from the excess momentum flux caused by waves. The swash oscillation of incident waves on the shoreline is a random process. A statistical parameter describing the $2 \%$ exceedance of all runup is defined by (Komar 1998) as:

$$
R_{2}=2 \eta_{\max }
$$

In CMS-Wave, $R_{2}$ is calculated at the land-water interface and averaged with the local depth to determine if the water can flood the proceeding dry cell. If the wave runup level is higher than the adjacent land cell elevation, CMS-Wave will flood the dry cells and simulate wave overtopping and overwash at them. In areas which have been flooded to allow overland wave propagation, the maximum water level is computed as the wave amplitude plus the wave setup, or, $\eta+0.5 \mathrm{H}_{1 / 3}$, where $\mathrm{H}_{1 / 3}$ is wave height. In low lying regions removed from overland wave propagation, water may flood strictly due to static water level increases by storm surge and tide. Thus, over the entire model domain the maximum flooding depth is computed using the following relation: 


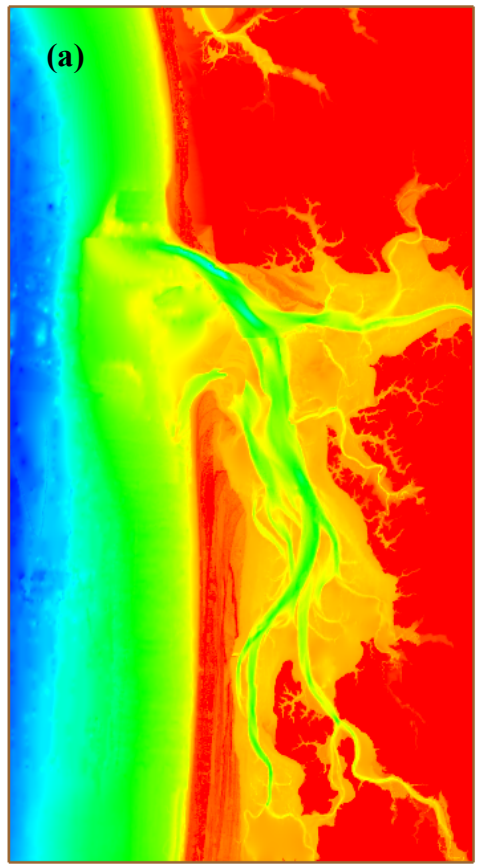

(c)
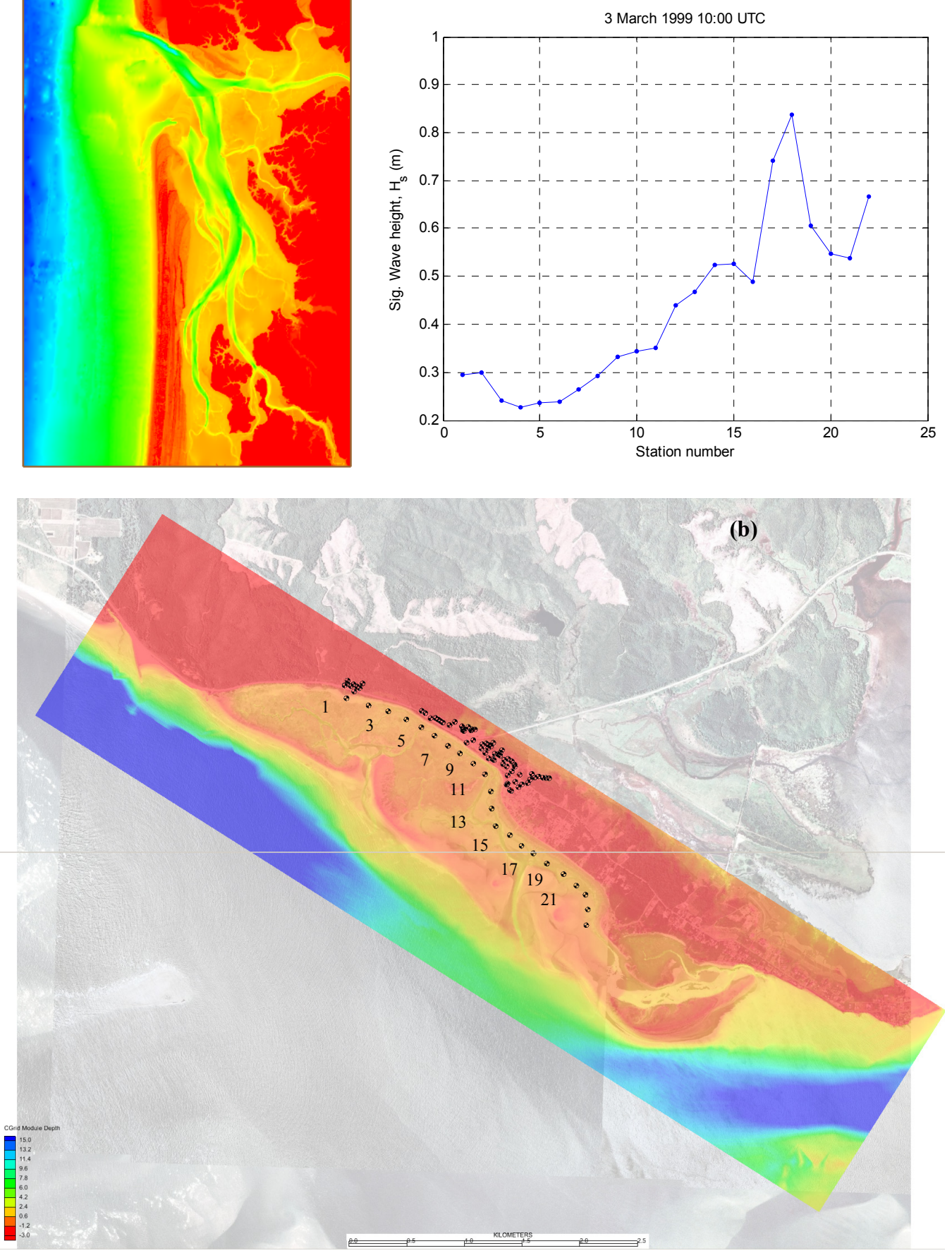

Figure 5. CMS-WAVE model domain (a) Coarse grid; (b) nested grid with observation cell locations (water depth in meters, MTL); (c) calculated wave height in meters for 3 March 1999 10:00 UTC simulation at observation stations. 
Maximum flooding depth $=$

$\max \left(R_{2}, \eta+0.5 \mathrm{H}_{1 / 3}\right)+$ tide elevation + surge elevation - land elevation

In shallow water, the maximum velocity of the wave (or celerity) is only a function of water depth thus the velocity of overland wave propagation is approximated as

$$
V=\sqrt{g h}
$$

where $g$ is gravitational acceleration and $h$ is the local water depth. This is a simple approximation of the velocity as the true velocity will be affected by substrate type and vegetation. However, the intent of this analysis is to develop a simple metric used to objectively identify potential consequences associated with overland wave propagation to susceptible infrastructure.

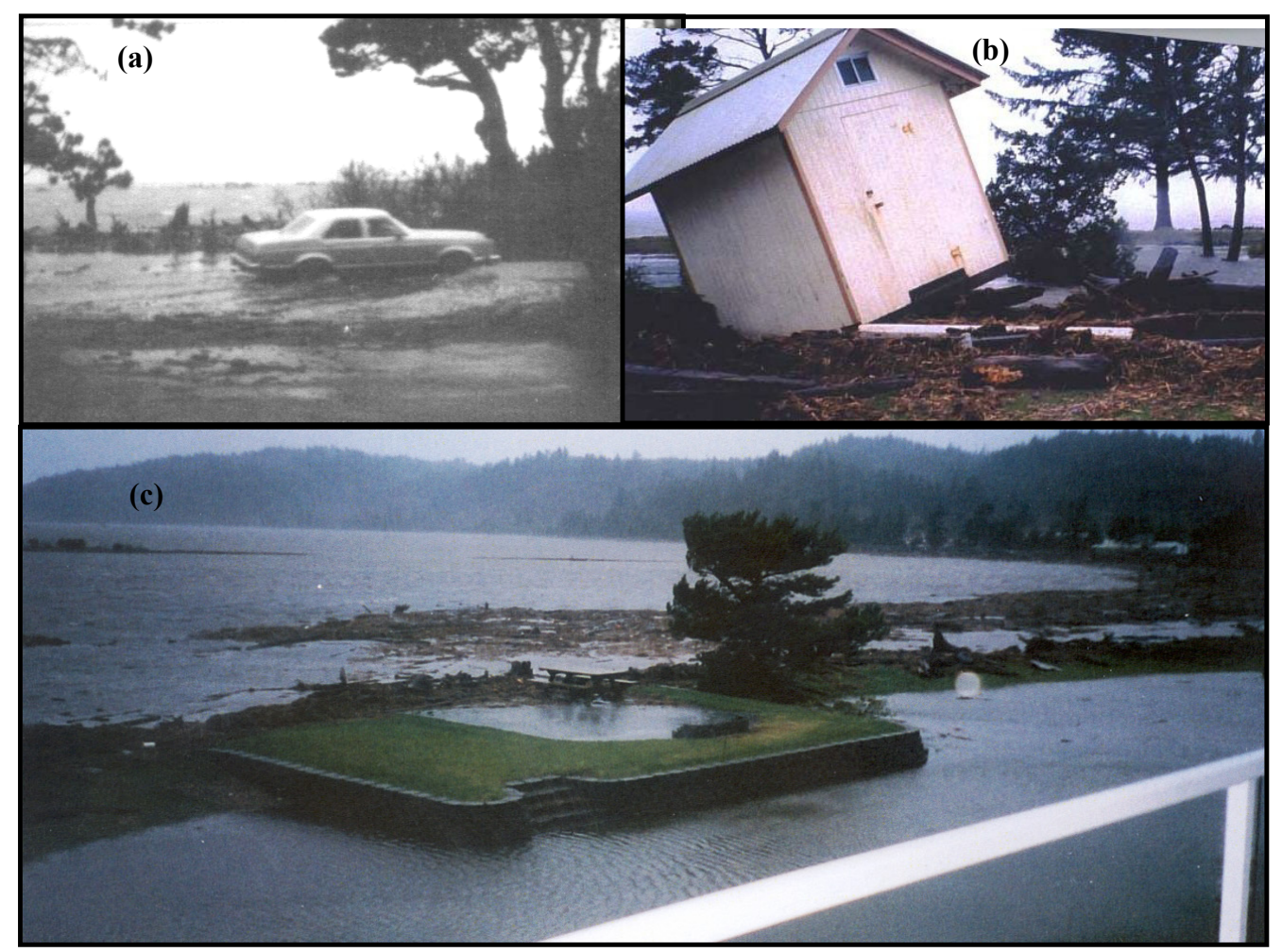

Figure 6. Inundation of Shoalwater Indian Reservation uplands and damage to structures (a) 3 March 1999 storm (b) 4 February 2006 storm (c) 4 February 2006 storm

\section{PROPOSED PLAN}

\section{Dune sizing}

The dune restoration alternative is intended to restore the eroded barrier island dune system with sand dredged from the adjacent Willapa Bay north entrance channel. The crest elevation is designed to minimize the risk of wave overtopping and maintain a sufficient sand reservoir following a 100 year storm event. In the narrowest section the cross-sectional area of the dune above mean high water (MHW) is $1785 \mathrm{ft}^{2}$ per lineal foot. The restored dune is 12,500 -feet-long, with a top elevation of +25 feet MLLW, a crest width of 20 feet, and a side slope of $1 \mathrm{~V}$ on $5 \mathrm{H}$. In the updrift reach and region where the breach will be closed a protective beach berm will be constructed at elevation $+15 \mathrm{ft}$ MLLW. Design details are included in (USACE 2009). The initial dune restoration requires approximately 700,000 cubic yards (CY) of sand dredged from the entrance to Willapa Bay. It is estimated the dune will need to be renourished every five years with approximately $250,000 \mathrm{CY}$ of dredge material. To reduce aeolian transport, the leeside crest and sideslope of the constructed dune will be planted with native dune grass. 


\section{Borrow pit sizing}

The relative water depth $k h$ of the incident wave conditions, borrow pit cross shore width, and borrow pit depth have the greatest potential to modify the surrounding wave environment through the processes of wave reflection, refraction and diffraction (Michalsen 2004; Michalsen and Haller 2008). To minimize impacts to wave and currents the borrow pit orientation is designed to follow the contours of the North Entrance channel sideslope. The dredge cut will be approximately $8 \mathrm{ft}$ below the existing seabed and have a footprint of 180 acres. Since 2000 this area has accreted approximately $0.75 \mathrm{MCY}$ per year as the channel has migrated southward. The north entrance channel presently exhibits depths of $90 \mathrm{ft}$ in the thalweg, and the effect of the borrow pit essentially widens the channel. Figure 7 displays the effect of the borrow pit and has relatively minor effects on the wave climate $(<0.3 \mathrm{ft}$, or $0.1 \mathrm{~m}$ change) from the existing configuration.

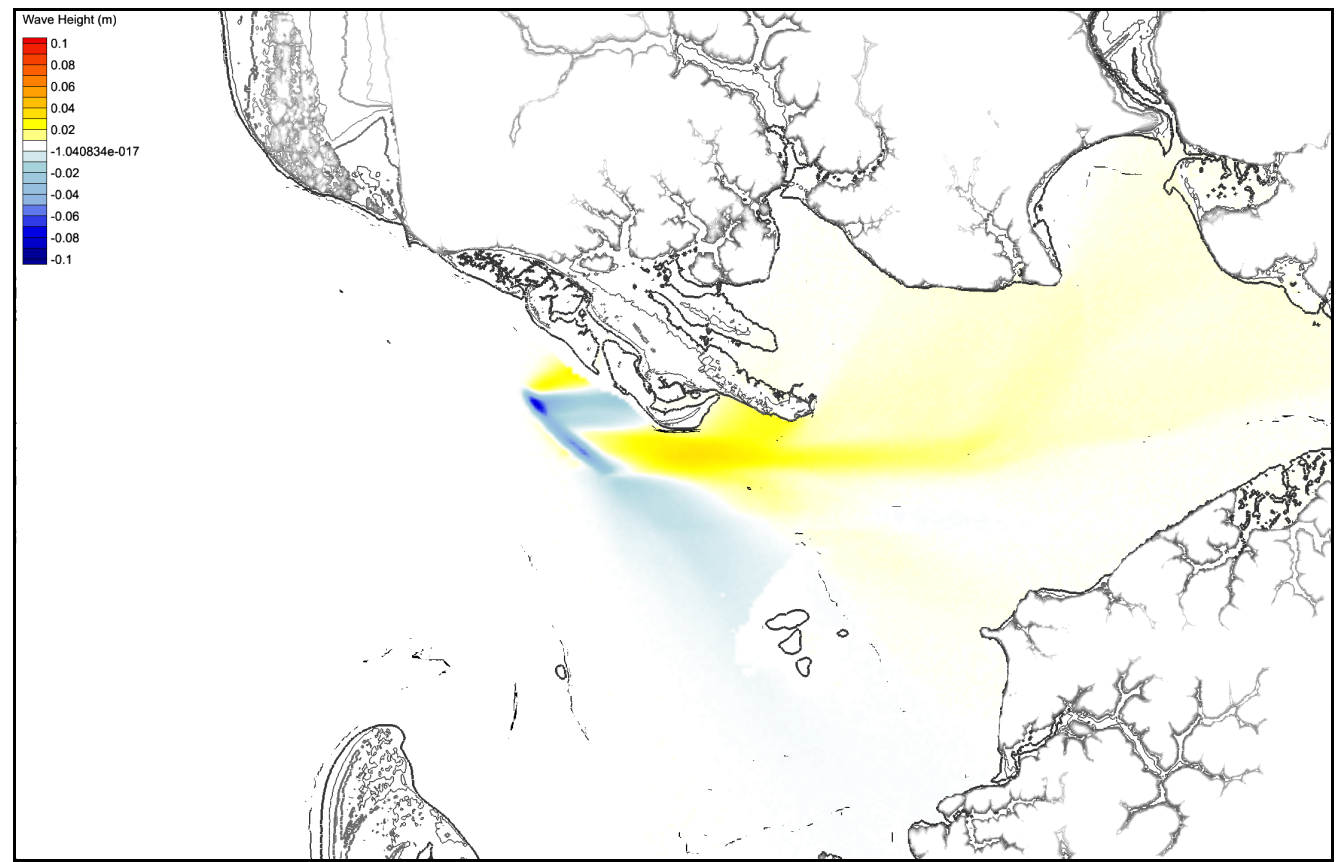

Figure 7. Change in wave height following dredging of the proposed borrow pit (March 3, 1999 storm)

\section{RISK ANALYSIS}

\section{Without project condition}

Damage to structures from coastal flooding is often related to flood depth or velocity of flood waters (FEMA 2005). High velocity flow associated with wave runup, overtopping, and overland wave propagation has the potential of transporting damaging debris. Potential damages associated with flooding can occur to SR 105, private residences, and property owned by the Shoalwater Indian Reservation. A structure inventory was performed for all property located within the Reservation Boundary in (USACE 2009). Flooding depth is a function of the proximity to the shoreline and the structures first floor elevation and adjacent grade. The threat of flooding is assigned using the following classification risk matrix presented in Table 3. A flooding threat to a structure is defined as any classification exceeding a low threat (L). As a validation set, the March 3, 1999 storm resulted in $54 \%$ of the structures classified with a flooding threat. Figure 8 shows a detailed inundation map for the March 3, 1999 storm. Documented damages by local residents during the storm confirm model results to be reasonable at predicting inundation depths.

The same approach is utilized to describe the threat during the 50,2, and $1 \%$ annual storm surge occurrence intervals. Table 4 lists the flooding risk of Shoalwater Reservation structures for each occurrence interval at MHHW and MAT, respectively. For a 2\% annual storm surge occurring during MAT, $92 \%$ of the structures inventoried are classified with a medium or high flooding risk. 


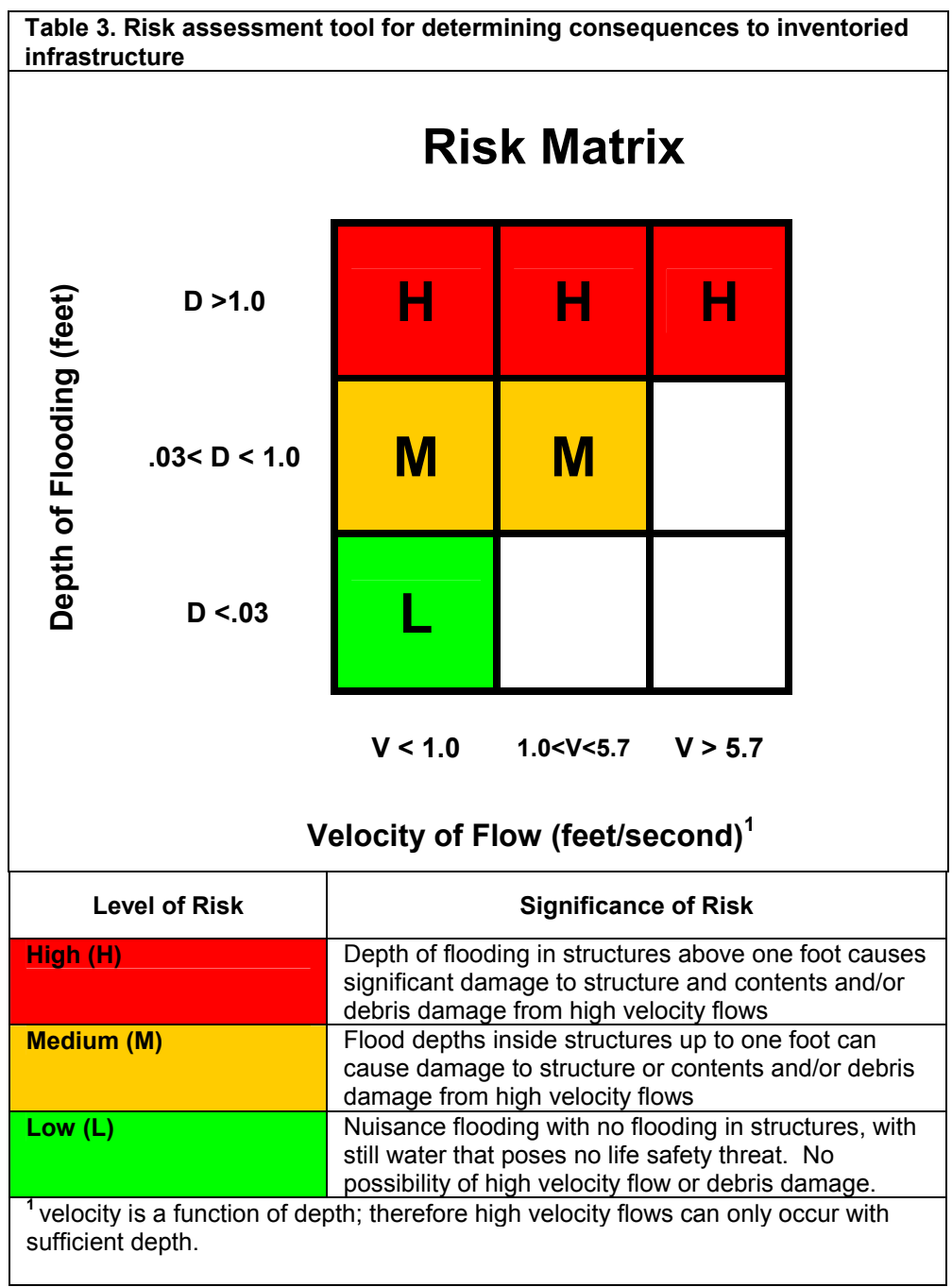

\begin{tabular}{|c|c|c|c|c|c|c|}
\hline & \multicolumn{3}{|c|}{ MHHW } & \multicolumn{3}{|c|}{ MAT } \\
\hline $\begin{array}{c}\text { Flood and } \\
\text { Storm } \\
\text { Damage } \\
\text { Risk } \\
\end{array}$ & $\begin{array}{l}50 \% \text { Annual } \\
\text { Occurrence }\end{array}$ & $\begin{array}{l}2 \% \text { Annual } \\
\text { Occurrence }\end{array}$ & $\begin{array}{l}1 \% \text { Annual } \\
\text { Occurrence }\end{array}$ & $\begin{array}{l}50 \% \text { Annual } \\
\text { Occurrence }\end{array}$ & $\begin{array}{l}2 \% \text { Annual } \\
\text { Occurrence }\end{array}$ & $\begin{array}{l}1 \% \text { Annual } \\
\text { Occurrence }\end{array}$ \\
\hline Low & 85 & 17 & 12 & 9 & 8 & 8 \\
\hline Medium & 7 & 40 & 35 & 35 & 12 & 12 \\
\hline High & 8 & 43 & 53 & 56 & 80 & 80 \\
\hline
\end{tabular}

\section{With project condition}

North Cove will continue to be hydraulically connected to Willapa Bay through two inlets. However, the restored dune will significantly reduce the frequency and magnitude of dynamic water level flooding due to wave runup and overland wave propagation. Figure 9 depicts the new risk 
assessment following dune restoration. The risk to the inventoried structures is reduced from $54 \%$ (without project) to 7\% (with project) during the March 3, 1999 storm condition. Additionally for the 6 hypothetical cases, flood risk is significantly reduced ( $>70 \%$ for MHHW and $>24 \%$ for MAT) as displayed in Table 5. During storm conditions, the restored dune will mitigate structure damage from debris carried inland by high velocity sheet flows. However, instances of extreme water levels caused by large storm surges at MAT will still flood low lying topography, thus some residual flooding risk to structures will exist even with the restored dune.

\begin{tabular}{|c|c|c|c|c|c|c|}
\hline & \multicolumn{3}{|c|}{ MHHW } & \multicolumn{3}{|c|}{ MAT } \\
\hline $\begin{array}{c}\text { Flood and } \\
\text { Storm } \\
\text { Damage } \\
\text { Risk }\end{array}$ & $\begin{array}{l}50 \% \text { Annual } \\
\text { Occurrence }\end{array}$ & $\begin{array}{l}2 \% \text { Annual } \\
\text { Occurrence }\end{array}$ & $\begin{array}{l}1 \% \text { Annual } \\
\text { Occurrence }\end{array}$ & $\begin{array}{l}50 \% \text { Annual } \\
\text { Occurrence }\end{array}$ & $\begin{array}{l}2 \% \text { Annual } \\
\text { Occurrence }\end{array}$ & $\begin{array}{l}1 \% \text { Annual } \\
\text { Occurrence }\end{array}$ \\
\hline Low & 100 & 87 & 83 & 83 & 37 & 32 \\
\hline Medium & 0 & 8 & 6 & 6 & 19 & 15 \\
\hline High & 0 & 5 & 11 & 11 & 44 & 53 \\
\hline $\begin{array}{l}\% \text { reduced } \\
\text { to Low }\end{array}$ & 15 & 70 & 71 & 74 & 29 & 24 \\
\hline
\end{tabular}

\section{CONCLUSIONS}

The U.S. Army Corps of Engineers has determined barrier island dune restoration as the most feasible alternative for storm damage reduction at the Shoalwater Indian Reservation in Willapa Bay, Washington USA. Extreme water levels coincident with strong winter storms are capable of inundating this low lying topography following the erosion and overwash of the protective barrier islands known as Graveyard Spit. The proposed plan would dredge material from the Willapa Bay north entrance channel to close an existing breach and reconstruct the dune on Graveyard Spit to mitigate flood damages to the Reservation shoreline and uplands.

To quantify the benefits of the project, a simple tool is presented for identifying flood risk to the Shoalwater Indian Reservation infrastructure. Statistical analysis of extreme water levels and numerical modeling is utilized to determine the extent of inundation in the Reservation. In the current condition, it was determined $54 \%$ of the inventoried infrastructure on the Shoalwater Indian Reservation is at risk during the March 3, 1999 storm event. With the barrier island restoration in place it was found that this risk is reduced to $7 \%$. 


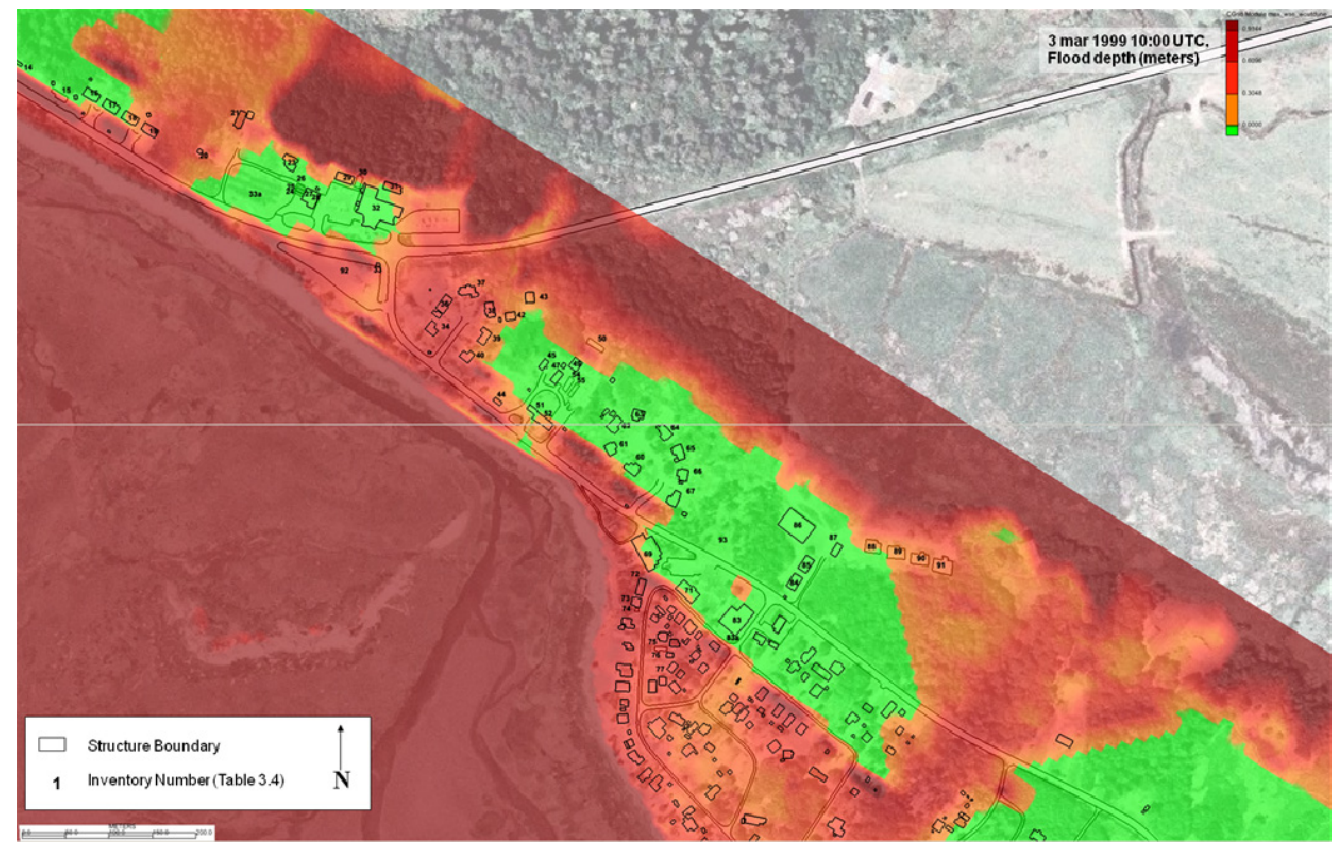

Figure 8. Without project risk assessment for Shoalwater Reservation infrastructure (March 3, 1999 storm)

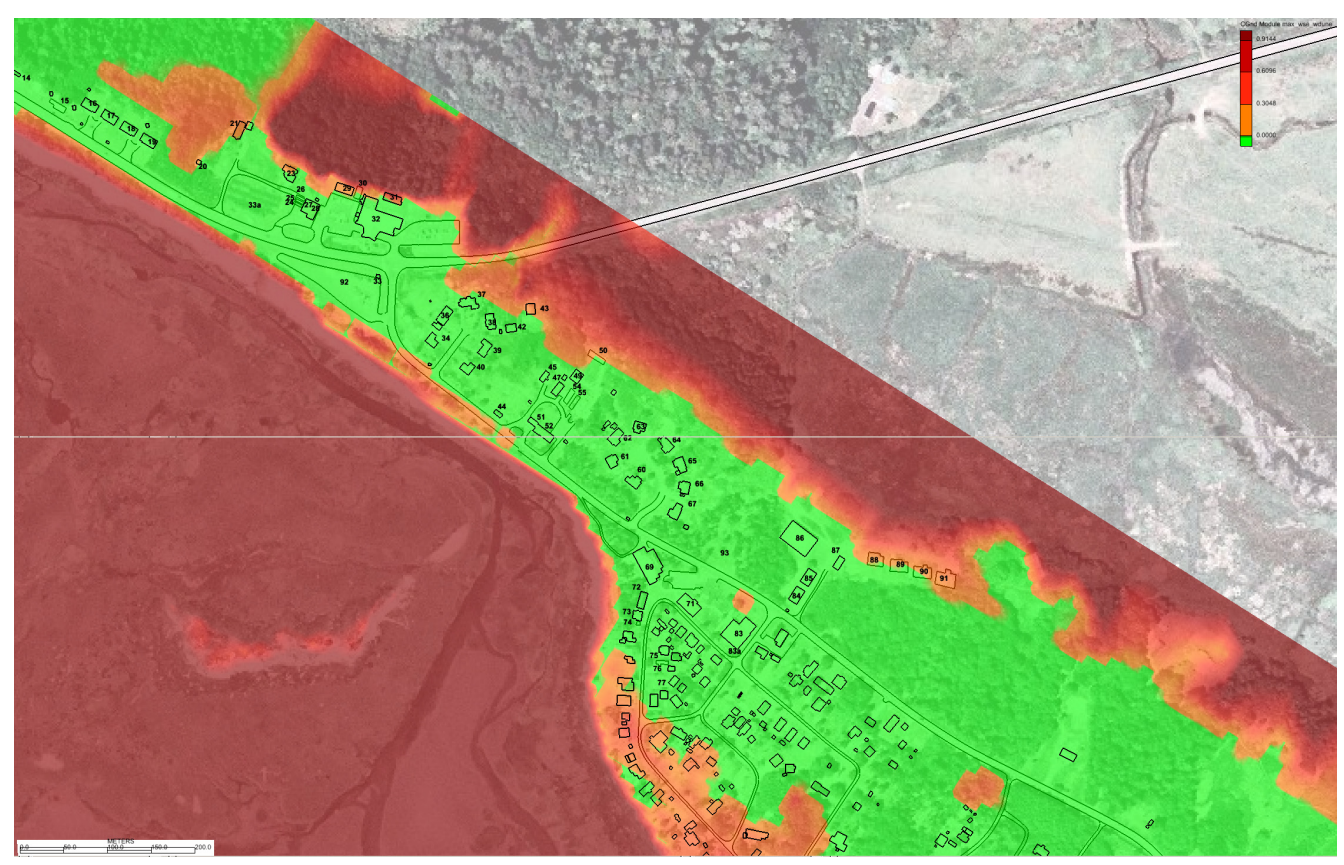

Figure 9. With project risk assessment for Shoalwater Reservation infrastructure (March 3, 1999 storm) 


\section{REFERENCES}

FEMA 2005. Guidelines for Coastal Flood Hazard Analysis and Mapping for the Pacific Coast of the United States http://www.fema.gov/plan/prevent/fhm/frm_cfham.shtm

Goda, Y. 2000. Random seas and design of maritime structures, World Scientific, Singapore.

Komar, P. D. 1998. Beach processes and sedimentation. 2nd ed. Upper Saddle River, NJ: PrenticeHall, Inc.

Kraus, N. C. (Editor). 2000. Study of Navigation Channel Feasibility, Willapa Bay, Washington. ERDC/CHL TR-00-6. Vicksburg, MS: U.S. Army Engineer Research and Development Center, Coastal and Hydraulics Laboratory.

Lin, L.,Demirbilek, Z., Mase, H., Zheng, J. and F. Yamada. 2008. CMS-WAVE: A nearshore spectral wave processes model for coastal inlets and navigation projects. Coastal and Hydraulics Engineering Technical Report ERDC/CHL TR-08-13. Vicksburg, MS: U.S. Army Engineer Research and Development Center.

Mase, H. 2001. Multi-directional random wave transformation model based on energy balance equation. Coastal Engineering Journal 43(4), 317-337.

Mase, H., K. Oki, T. Hedges, and H. J. Li. 2005. Extended energy-balance-equation wave model for multi-directional random wave transformation. Ocean Engineering 32, 961-985.

Michalsen, D.R. 2004. An investigation of wave field transformation and shoreline morphology near steep bathymetric features." Masters' thesis, Dept. of Civil, Construction and Environmental Engineering, Oregon State Univ., Corvallis, Ore.

Michalsen, D., Haller, M.C. and Suh, K-D. 2008. Wave reflection from nearshore depressions, $J$. Waterway, Port, Coastal, and Ocean Engineering, 134(1), 1-11.

Pugh, D.T. and Vassie, J.M. 1978. Extreme sea levels from tide and surge probability. Proc. 16th Coastal Engineering Conference. Hamburg, Germany. pp. 911-930

Taylor, L.A., B.W. Eakins, K.S. Carignan, and R.R. Warnken. 2008. Digital Elevation Model for Astoria, Oregon: Procedures, Data Sources and Analysis. Prepared for the Pacific Marine Environmental Laboratory (PMEL) NOAA Center for Tsunami Research by the NOAA National Geophysical Data Center (NGDC). May 30, 2008

Terich, T., and T. Levenseller. 1986. The Severe Erosion of Cape Shoalwater, Washington. Journal of Coastal Research, Vol. 2, No. 4, pp. 465-477.

U.S. Army Corps of Engineers, Seattle District. 2009a, Final Post-Authorization Decision Document: Shoalwater Bay Shoreline Erosion, Washington.

U.S. Army Corps of Engineers, Seattle District. 2009b, Appendix 1: Engineering Analysis and Design Shoalwater Bay Shoreline Erosion, Washington.

USGS 2004. Shoalwater Bay Tribe Erosion Study. Prepared in Cooperation with Washington Department of Ecology. Unpublished report. 